\title{
AWARENESS OF EXPORT PROMOTION PROGRAMS - A PERSPECTIVE
}

\author{
Gitanjali Jindal $^{1}$ and Kamlesh Gakhar ${ }^{2}$
}

\begin{abstract}
The study attempted to investigate the awareness of the exporting assistance programs offered by Indian Government. The data for the study was collected through the mailed questionnaires and face to face interviews with the exporting firms. A wide range of export promotion programs available in India to help firms penetrating into export markets. However, firms must first be aware of the availability of these promotion programs before they can make use of them. Data collected from 294 manufacturing firms indicated that the firms' overall awareness of export programs was not high. The results suggested that government agencies, in particular, need to do more to promote their role in developing external trade.

Keyword-Economic Development, Economic Growth, Export Promotion Schemes
\end{abstract}

\section{INTRODUCTION}

Exports play an important role in the economic growth of the country. To boost up the export Indian government has introduced number of schemes time to (Cavusgil and Yeoh, 1994;Jaramillo, 1992). The main objective of export promotion programs is to enhance export performance by firm's capabilities and overall abilities, resources and strategies and overall competitiveness (Czinkota, 1996; Diamantopoulous et al; 1993, Seringhous and Rosson; 1990). The purpose of the research was to assess the level of awareness of exporters about various export promotion schemes.

\section{Export Promotion Schemes}

\begin{tabular}{|l|l|}
\hline 1 & Advance Authorization Scheme \\
\hline 2 & Duty Free Import Authorization (DFIA) \\
\hline 3 & Served from India Scheme \\
\hline 4 & Export Promotion Capital Goods (EPCG) Scheme \\
\hline 5 & Reward Scheme- Focus Market Scheme (FMS) \\
\hline 6 & Reward Scheme- Focus Product Scheme (FPS) \\
\hline
\end{tabular}

\footnotetext{
${ }^{1}$ Research Scholar, IMSAR, M.D. University, Rohtak (Haryana)

${ }^{2}$ Professor, IMSAR, M.D. University, Rohtak (Haryana)
} 


\begin{tabular}{|l|l|}
\hline 7 & Reward Scheme- Market Linked Focus Products Scrip \\
\hline 8 & Status Holders Incentive Scrip (SHIS) \\
\hline 9 & Schemes Related to gems \& Jewellery \\
\hline 10 & Assistance to States for Infrastructure Development of Exports \\
\hline 11 & The Market Access Initiative (MAI) Scheme \\
\hline 12 & The Marketing Development Assistance (MDA) Scheme \\
\hline
\end{tabular}

\section{REVIEW OF LITERATURE}

Moini (1998) examined the impact of Export Promotion Programs on the export activities in US State of Wisconsin. He divided firms into four categories: non exporters, regular exporters, growing exporters and partially invested exporters. He found that lack of export awareness about Export Promotion Programs was more in non exporters and partially interested exporters.

Burning (1995) examined the relationship between Export Promotion Programs and exporter's awareness regarding programs. Kedia and chhokar (1986), studied the use of export Promotion Programs for exporters and non exporters in Louisana. They added that awareness of these programs was very low among the exporters. So, it is clear that a fairly large number of small and medium-sized firms expect considerable benefits from some of the existing programs and are also willing to use them. There is a significant relationship between export promotion programs and export performance of the firms. Export promotion programs improve the firm performance, competencies and strategies Czinkota (1996), Francis and Collins (2004). More awareness of export promotion programs affects the success in export market to the exporters. Export promotion programs are used by the exporters according to the level of their involvement in exporting. Some of the studies showed that no significant relationship exist between awareness of the program and performance of the company Marandu (1995). Crick and Czinkota (1995) found that the Export promotion Programs provided by the government were different from the need of programs of the exporters.

Ahmed (2002) discovered the positive significant relationship between awareness of export promotion programs and size of the firms. This study examined the channels of information through which Malaysian firms get information regarding export promotion programs, and assessed the level of awareness of 13 such programs among Malaysian firms in four industry groups (1) Basic Metals (93 firms); (2) Fabricated Metals (172 firms); (3) Machinery and Equipment (171 firms); and (4) Non-Metallic Mineral Products (93 firms). Linnemann et al. (1987) discussed the export promotion programs used by 17 developing countries with differences in political, economic, and structural characteristics, such as level of economic development and industrialization, size of domestic market, population density, and natural resources.

\section{Objectives of the study}

The major objectives of this study are as follows

1. To assess the level of awareness and usage of export promotion programs among firms in different sectors.

2. To assess the level of awareness and usage of export promotion programs among firms on the basis of export experience 


\section{Research Methodology}

The present research attempts to study the exporter's perception of the export promotion schemes in the NCR and Haryana in relation to five export sectors comprising of engineering, textile, gems and jewellery, chemical and leather. Primary data was collected from the exporters working in the selected export sectors. At present there are 12 export promotion schemes related to export promotion in India. In this Dichotomous question was asked to the exporters regarding awareness. In total 294 valid responses were obtained. The response rate was 58.8 per cent. The collected data were analyzed using the Statistical Package for Social Science (SPSS) Version 17.0.

\section{Findings and Analysis}

Table: 1 Summary of Number of exporters

\begin{tabular}{|c|c|c|}
\hline S.No. & Item & Percent \\
\hline 1 & Textile & 25.5 \\
\hline 2 & Gems and Jewellery & 15.3 \\
\hline 3 & Leather & 22.1 \\
\hline 4 & Chemical & 15 \\
\hline 5 & Engineering & 22.1 \\
\hline & Total & 100 \\
\hline
\end{tabular}

Source: Surveyed data

As shown in the above Table 1 Out of 294 exporting firms, 75 valid responses obtained from the exporters of textile sector, 45 valid responses from gems and jewellery sector, 65 valid responses from leather ,44 responses were achieved from chemical sector and 65 responses from engineering sector.

\section{Total awareness level of the exporters}

Table 2 below presents the percentages of the responses to the questions on the awareness of the 12 export assistance programs as recorded from the 294 respondents in the study.

Table: 2 Total awareness level of the exporters

\begin{tabular}{|c|c|c|c|c|c|c|c|c|c|c|c|}
\hline \multirow{5}{*}{ Advance Authorization Scheme } & \multirow[t]{2}{*}{ Item } & \multirow[t]{2}{*}{ Total } & \multicolumn{5}{|c|}{ Sector wise } & \multicolumn{4}{|c|}{ Export experience wise } \\
\hline & & & Textile & $\begin{array}{c}\text { Gems } \\
\text { and } \\
\text { Jewellery }\end{array}$ & Leather & Chemical & Engineering & $\begin{array}{c}1-5 \\
\text { years }\end{array}$ & $\begin{array}{c}6-10 \\
\text { years }\end{array}$ & $\begin{array}{l}11-16 \\
\text { years }\end{array}$ & $\begin{array}{c}\text { over } 16 \\
\text { years }\end{array}$ \\
\hline & Yes & $264(89.7 \%)$ & 90.7 & 84.4 & 100 & 93.2 & 80 & 87 & 92.79 & 82.2 & 91.66 \\
\hline & No & $30(10.3 \%)$ & 9.3 & 15.6 & $\mathbf{0}$ & 6.8 & 20 & 13 & 7.21 & 17.8 & 8.33 \\
\hline & Total & 294 & $(75) 100$ & $(45) 100$ & $(65) 100$ & $(44) 100$ & $(65) 100$ & $(54) 100$ & (111)100 & (45)100 & $(84) 100$ \\
\hline \multirow{3}{*}{$\begin{array}{l}\text { Duty Free Import Authorization } \\
\text { (DFIA) }\end{array}$} & Yes & $218(74.1 \%)$ & 54.7 & 57.8 & 100 & 88.6 & 72.3 & 72.2 & 74.8 & 68.9 & 77.4 \\
\hline & No & $76(25.9)$ & 45.3 & 42.2 & $\mathbf{0}$ & 11.4 & 27.7 & 27.8 & 25.2 & 31.1 & 22.6 \\
\hline & Total & 294 & $(75) 100$ & $(45) 100$ & $(65) 100$ & $(44) 100$ & $(65) 100$ & (54)100 & (111)100 & (45) 100 & $(84) 100$ \\
\hline \multirow{3}{*}{ Served from India Scheme } & Yes & $82(27.89 \%)$ & 5.3 & 0 & 33.8 & 34.1 & 63.1 & 22.2 & 24.3 & 28.9 & 35.7 \\
\hline & No & $212(72.11 \%)$ & 94.7 & 100 & 66.2 & 65.9 & 36.9 & 77.8 & 75.7 & 71.1 & 64.3 \\
\hline & Total & 294 & (75) 100 & (45) 100 & $(65) 100$ & (44)100 & (65) 100 & (54)100 & (111)100 & (45)100 & $(84) 100$ \\
\hline \multirow{3}{*}{$\begin{array}{l}\text { Export Promotion Capital } \\
\text { Goods (EPCG) Scheme }\end{array}$} & Yes & $191(64.96 \%)$ & 48 & 22.2 & 98.5 & 81.8 & 69.2 & 50 & 67.6 & 66.7 & 70.2 \\
\hline & No & $103(35.04 \%)$ & 52 & 77.8 & 1.5 & 18.2 & 30.8 & 50 & 32.4 & 33.3 & 29.8 \\
\hline & Total & 294 & $(75) 100$ & $(45) 100$ & $(65) 100$ & (44)100 & $(65) 100$ & $(54) 100$ & (111)100 & $(45) 100$ & $(84) 100$ \\
\hline \multirow{3}{*}{$\begin{array}{c}\text { Reward Scheme- Focus Market } \\
\text { Scheme (FMS) }\end{array}$} & Yes & $128(43.5 \%)$ & 52 & 8.9 & 3.1 & 86.4 & 69.2 & 40.7 & 92.8 & 40 & 58.3 \\
\hline & No & $166(56.5 \%)$ & 48 & 91.1 & 96.9 & 13.6 & 30.8 & 59.3 & 7.2 & 60 & 41.7 \\
\hline & Total & 294 & (75) 100 & (45) 100 & $(65) 100$ & (44)100 & $(65) 100$ & (54) 100 & (111)100 & (45)100 & $(84) 100$ \\
\hline \multirow{3}{*}{$\begin{array}{c}\text { Reward Scheme- Focus Product } \\
\text { Scheme (FPS) }\end{array}$} & Yes & $102(34.7 \%)$ & 49.3 & 6.7 & 1.5 & 70.5 & 46.2 & 33.3 & 27.9 & 31.1 & 46.4 \\
\hline & No & $192(65.3 \%)$ & 50.7 & 93.3 & 98.5 & 29.5 & 53.8 & 66.7 & 72.1 & 68.9 & 53.6 \\
\hline & Total & 294 & (75) 100 & (45)100 & $(65) 100$ & $(44) 100$ & $(65) 100$ & (54)100 & (111)100 & (45) 100 & $(84) 100$ \\
\hline Reward Scheme- Market & Yes & $95(32.3 \%)$ & 45.3 & 4.4 & $\mathbf{0}$ & 45.5 & 60 & 27.8 & 23.4 & 26.7 & 50 \\
\hline
\end{tabular}




\begin{tabular}{|c|c|c|c|c|c|c|c|c|c|c|c|}
\hline \multirow[t]{2}{*}{ Linked Focus Products Scrip } & No & $199(67.7 \%$ & 54.7 & 95.6 & 100 & 54.5 & 40 & 72.2 & 76.6 & 73.3 & 50 \\
\hline & Total & 294 & (75) 100 & (45)100 & $(65) 100$ & (44) 100 & $(65) 100$ & (54) 100 & (111)100 & (45) 100 & (84) 100 \\
\hline \multirow{3}{*}{$\begin{array}{l}\text { Reward Scheme- Status Holders } \\
\text { Incentive Scrip (SHIS) }\end{array}$} & Yes & $64(21.7 \%)$ & 45.3 & $\mathbf{0}$ & $\mathbf{0}$ & 45.5 & 15.4 & 20.4 & 18 & 20 & 28.6 \\
\hline & No & $230(78.3 \%)$ & 54.7 & 100 & 100 & 54.5 & 84.6 & 79.6 & 82 & 80 & 71.4 \\
\hline & Total & 294 & (75)100 & (45)100 & $(65) 100$ & (44) 100 & $(65) 100$ & (54) 100 & (111)100 & (45) 100 & (84) 100 \\
\hline \multirow{3}{*}{$\begin{array}{c}\text { Schemes Related to gems \& } \\
\text { Jewellery }\end{array}$} & Yes & $55(18.7 \%)$ & 2.7 & 93.3 & $\mathbf{0}$ & 4.5 & 13.8 & 35.2 & 21.6 & 15.6 & 6 \\
\hline & No & $239(81.3 \%)$ & 97.3 & 6.7 & 100 & 95.5 & 86.2 & 64.8 & 78.4 & 84.4 & 94 \\
\hline & Total & 294 & (75)100 & (45)100 & $(65) 100$ & (44)100 & (65)100 & (54) 100 & (111)100 & (45) 100 & (84)100 \\
\hline \multirow{3}{*}{$\begin{array}{l}\text { Assistance to States for } \\
\text { Infrastructure Development of } \\
\text { Exports }\end{array}$} & Yes & $88(29.9 \%)$ & 1.3 & 2.2 & 70.8 & 20.5 & 47.7 & 20.4 & 29.7 & 28.9 & 36.9 \\
\hline & No & $206(70.1 \%)$ & 98.7 & 97.8 & 29.2 & 79.5 & 52.3 & 79.6 & 70.3 & 71.1 & 63.1 \\
\hline & Total & 294 & (75)100 & (45)100 & $(65) 100$ & (44) 100 & (65) 100 & (54) 100 & (111)100 & (45) 100 & (84) 100 \\
\hline \multirow{3}{*}{$\begin{array}{l}\text { The Market Access Initiative } \\
\text { (MAI) Scheme }\end{array}$} & Yes & $123(41.8 \%)$ & 6.7 & 28.9 & 98.5 & 43.2 & 33.8 & 35.2 & 47.7 & 40 & 39.3 \\
\hline & No & $171(58.2 \%)$ & 93.3 & 71.1 & 1.5 & 56.8 & 66.2 & 64.8 & 52.3 & 60 & 60.7 \\
\hline & Total & 294 & (75)100 & (45)100 & $(65) 100$ & (44) 100 & (65) 100 & (54) 100 & (111)100 & (45) 100 & (84) 100 \\
\hline \multirow{3}{*}{$\begin{array}{l}\text { The Marketing Development } \\
\text { Assistance (MDA) Scheme }\end{array}$} & Yes & $108(36.7 \%)$ & 13.3 & 15.6 & 33.8 & 59.1 & 66.2 & 25.9 & 34.2 & 44.4 & 42.9 \\
\hline & No & $186(63.3 \%)$ & 86.7 & 84.4 & 66.2 & 40.9 & 33.8 & 74.1 & 65.8 & 55.6 & 57.1 \\
\hline & Total & 294 & $(75) 100$ & (45)100 & $(65) 100$ & (44)100 & (65)100 & (54) 100 & (111)100 & (45)100 & (84) 100 \\
\hline
\end{tabular}

Source: Surveyed data

\section{Advance Authorization Scheme}

Out of 294 respondents $264(89.7 \%)$ were found to be aware regarding this scheme, whereas 10 respondents were found to be not aware. So far as sector wise awareness of this scheme is concerned, it was found that in the leather sector all the respondents were aware of this scheme $(100 \%)$. The engineering sector showed the lowest level of awareness (80\%). As per the results, those respondents having 6-10 years export experience showed the highest level of awareness (92.8\%). 11-16 years experience respondents were least aware about this scheme $(82.2 \%)$.

\section{Duty Free Import Authorization}

Out of total respondents, $218(74.1 \%)$ were found to be aware regarding this scheme, whereas seventy six respondents were found to be unaware. It was found that all the respondents from leather sector were aware regarding this scheme (100\%). Textile sector respondents were found to be least aware $(54.7 \%)$. Over 16 years experience respondents showed the highest level of awareness (77.4\%). 11-16 years experience respondents indicates least aware about this scheme $(68.9 \%)$.

\section{Served from India Scheme}

Out of total respondents $82(27.89 \%)$ were aware regarding this scheme, whereas 212 respondents were not aware. Engineering sector respondents showed the highest level of awareness $(63.1 \%)$. All the respondents from gems and Jewellery showed lack of awareness of this scheme. Over the 16 years export experience showed the highest level of awareness $(35.7 \%)$. 1-5 years experience respondents were found to be least aware about this scheme (22.2\%). These results are similar with the study of Ahmed (2002), which has mentioned that there was significant difference between the new and experience exporters in their awareness level regarding export promotion schemes.

\section{Export Promotion Capital Goods Scheme}


Out of 294 respondents $191(64.96 \%)$ were found to be aware regarding this scheme, whereas 103 respondents were not aware. Leather sector respondents displayed the highest level of awareness (98.5\%). Gems and jewellery sector respondents were found to be least aware (22.2\%). As per the results, Over 16 years export experience respondents indicated the highest level of awareness (70.2 \%). 1-5 years experience respondents were least aware about this scheme $(50 \%)$. More experience firms indicated significantly greater awareness than less experience firms.

\section{Reward Scheme-Focus Market Scheme}

Out of 294 respondents $128(43.5 \%)$ respondents were found to be aware regarding "Focus Market Scheme (FMS)". 166 respondents were unaware about this scheme. Overall, firms' awareness of this scheme was not very high. The respondents from chemical sector showed highest awareness regarding this scheme (86.4\%) and leather sector respondents showed lowest awareness $(3.1 \%)$ It is clear that chemical respondents were more aware about this scheme followed by engineering sector respondents.6-10 year experience respondents were more aware (92.8\%) of this scheme. The 11-16 year experience respondents showed the lowest level of awareness $(40 \%)$.

\section{Focus Product Scheme}

The ratio of awareness percentage regarding the Focus Product scheme is approx. 1:2. As per the results, out of the total respondents 102 (34.7\%) were aware of this scheme and 192 respondents were not aware. Maximum numbers of respondents was not aware regarding this scheme. Chemical sector respondents showed the highest awareness $(70.5 \%)$ followed by textile and engineering (49.3\%) and (46.2\%). The study showed that there was low percentage among gems and jewellery and leather respondents $6.7 \%$ and $1.5 \%$.Over 16 years respondents were aware (46.4\%) of this scheme followed by 1-5 years and 11-16 years (33.3\% and 31.1\% ). 6-10 years experience respondents showed the lowest level of awareness (27.9\%).

\section{Market Linked Focus Products Scrip}

The trend awareness the percentage regards MLFPS is almost the same as FPS and again is of approximately same ratio. The number of unaware respondents came out to be $199(67.6 \%)$ out of 294. The engineering respondents showed the maximum level of awareness $(60 \%)$ followed by chemical $(45.5 \%)$ and textile respondents $(45.3 \%)$. Gems and jewellery respondents were found to be least aware of this scheme (4.4\%) and it was found that in the leather sector all the respondents were unaware regarding this scheme. Over 16 years showed the highest level of awareness $(50 \%)$ followed by $1-5$ years $(27.8 \%)$ and $11-16$ years $(26.7 \%)$. it was found that 6-10 yeasr experience respondents were found to be least aware of this scheme (23.4\%).

\section{Reward Scheme - Status Holders Incentive Scrip}

Among the respondents 64 respondents $(27.9 \%)$ were found to be aware of this scheme and 230 respondents were not aware. The results showed that number of respondents were not aware and displayed lack of awareness regarding this scheme. Chemical and textile sector respondents were found to be more aware $(45.5 \% \& 45.3 \%)$ of this scheme followed by engineering sector respondents (15.4\%). It was found that all the gems and jewellery and leather sector respondents were unaware regarding this scheme. Over 16 years experience respondents showed the highest 
level of awareness (28.6\%) followed by 1-5 years (20.4\%) and 11-16 years experience respondents (20\%). 6-10 years respondents showed the lowest level of awareness (18\%).

\section{Schemes Related to Gems \& Jewellery}

The number of unaware respondents came out to be 239 out of total respondents. 55 (18.7\%) respondents were found to be aware regarding this scheme. Mainly Gems and jewellery sector showed the highest level of awareness. Almost all the gems and jewellery sector respondents were aware of this scheme (93.9\%). All the respondents from leather sector were found to be unaware related to this scheme. There was inverse relationship between export experience and level of awareness of the respondents about this scheme. 1-5 years experience respondents showed highest level of awareness $(35.2 \%)$ followed by 6-10 years experience respondents $(6 \%)$.

\section{Assistance to States for Infrastructure Development of Exports}

Out of total respondents 206 respondents were found to be unaware regarding this scheme. Only $29.9 \%$ i.e. 88 respondents were aware of this scheme. Leather respondents were found to be aware of this scheme (70.8\%) followed by engineering sector (47.7\%) and chemical $(20.5 \%)$. Textile and gems and jewellery respondents showed the lowest level of awareness with (1.3\%) and $(2.2 \%)$. Over 16 years experience respondents were aware of this scheme $(36.9 \%)$, followed by 6-10 years experience respondents $(29.7 \%)$ and $11-16$ years respondents $(28.9 \%)$. 1-5 years experience respondents showed lowest level of awareness $(20.4 \%)$.

\section{Market Access Initiative Scheme}

Out of total respondents $123(41.8 \%)$ respondents were found to be aware regarding this scheme. 171 respondents were not aware of this scheme. Leather sector almost all the respondents were aware of this scheme (98.5\%). Among selective sector, chemical sector respondents were found to be aware of this scheme (43.2\%), followed by engineering (33.8\%) and gems and jewellery (28.9\%). The textile sector respondents showed the lowest level of awareness (6.7\%). 6-10 year experience respondents were more aware (47.7\%) of this scheme. The 1-5 year experience respondents showed the lowest level of awareness (35.2\%). 11-16 year experience respondents were aware (40\%) followed by over 16 year respondents with $(39.3 \%)$.

\section{Marketing Development Assistance Scheme}

Out of 294 respondents 108(36.7\%) respondents were aware regarding this scheme. 106 respondents were not aware of this scheme. So far as sector wise awareness of this scheme is concerned, it was found that the engineering sector showed the highest level of awareness $(66.2 \%)$. Chemical sector respondents were found to be aware $(59.1 \%)$ followed by leather $(33.8 \%)$ and gems and jewellery (15.6\%). The textile sector respondents showed the lowest level of awareness (13.3\%). 11-16 years experience respondents showed the highest level of awareness (44.4\%). 1-5 years experience respondents displayed least awareness about this scheme $(25.9 \%)$.

Table: 3 Ranking of Export Promotion Schemes on the Basis of Awareness

\begin{tabular}{|l|c|c|}
\hline \multicolumn{1}{|c|}{ Scheme } & $\begin{array}{c}\text { No. of Respondents in } \\
\text { Percentage }\end{array}$ & Ranking \\
\hline Advance Authorization Scheme & 89.7 & 1 \\
\hline Duty Free Import Authorization & 74.1 & 2 \\
\hline Export Promotion Capital Goods Scheme & 64.9 & 3 \\
\hline
\end{tabular}




\begin{tabular}{|l|l|l|} 
Reward Scheme- Focus Market Scheme & 43.5 & 4 \\
\hline The Market Access Initiative Scheme & 41.8 & 5 \\
\hline The Marketing Development Assistance Scheme & 36.7 & 6 \\
\hline Reward Scheme- Focus Product Scheme & 34.7 & 7 \\
\hline Reward Scheme- Market Linked Focus Products Scrip & 32.3 & 8 \\
\hline Assistance to States for Infrastructure Development of Exports & 29.9 & 9 \\
\hline Served from India Scheme & 27.8 & 10 \\
\hline Status Holders Incentive Scrip & 21.7 & 11 \\
\hline
\end{tabular}

Source: Surveyed data

The awareness and ranking of export promotion schemes is shown in table no 3 . The results of the study indicate that percentages of the awareness vary among the responding firms. Relatively higher degree of awareness was associated with an Advance Authorization Scheme, Duty Free Import Authorization, Export Promotion Capital Goods Scheme, Reward Scheme- Focus Market Scheme, Market Access Initiative Scheme, Marketing Development Assistance Scheme, Reward Scheme- Focus Product Scheme and Reward Scheme- Market Linked Focus Products Scrip. Low degree of awareness was recorded in respect of Assistance to States for Infrastructure Development of Exports, Served from India Scheme and Status Holders Incentive Scrip Schemes.

\section{CONCLUSION}

The findings of the study revealed that significant difference is found in the awareness level of exporters on the basis of selected sector and experience. Awareness of Export Promotion Programs depends upon the stage of involvement of the exporters supported by Diamantopoulos et al. 1993.

\section{REFERENCES}

[1]. Ahmed.z and Johnson .J, "Export promotion programs of Malaysian firms: An international marketing "Journal of Business Research. October 2002.

[2]. Archer, Stephen H. and Steven M. Maser (1989), "State Export Promotion for Economic Development," Economic Development Quarterly, 3 (3), 235-242.

[3]. Bruning E. R. (1995). Strategic Positioning for Export Market Development: The Role of Managerial Attitudes, Export Development Programmes and Firm Characteristics, Journal of Strategic Marketing, 3, 127-143.

[4]. Campbell, D (1987). An empirical examination of selected target firms' perceptions of US Department of Commerce export promotion programs, University of Arkansas, AR., unpublished doctoral dissertation.

[5]. Cavusgil T.S. and Czinkota M.R. (1990). International Perspectives on Trade Promotion and Assistance, Quorum, New York.

[6]. Crick D. (1992) .UK export assistance: are we supporting the best programmes?, Journal of Marketing Management, 8, 81-92.

[7]. Crick, D. and Czinkota, M.R. (1995). Export assistance: another look at whether we are supporting the best programs, International Marketing Review, 12, 3, 61-72.

[8]. Czinkota M.R. and Johnston W.J. (1981). Segmenting US firms for export development, Journal of Business Research, 9, 253-65.

[9]. Czinkota and Tesar (1982). Export Management-An international Context, New York, Praegar Publishers.

[10]. Czinkota M.R (1983). Export Promotion: The Public and Private Sector Interaction, Praeger, New York.

[11]. Czinkota M.R. (1996). Why national export promotions?, International Trade Forum, 2, 10-13, 28.

[12]. Czinkota M.R. and Ricks D.A. (1981). Export assistance: are we supporting the best programs? Columbia Journal of World Business, 16, 73-80. 
[13]. Diamantopoulos A; Schlegelmilch B.B; and Tse K.Y (1993). Understanding the role of export marketing assistance: empirical evidence and research needs, European Journal of Marketing, 27, 4, 5-18.

[14]. http://dgftcom.nic.in/exim/2000/policy/chap-04.htm. Francis J. and Collins-Dodd C. (2004). Impact of export promotion programs on firm competencies, strategies and performance: The case of Canadian hightechnology SMEs", International Marketing Review, 21, 474-495.

[15]. Jalali S.H. (2012). The effect of export promotion programmes on export performance: evidence from Iranian food manufacturers, Int. J. Business and Globalisation, 9

[16]. Kedia B.L. and Chhokar J. (1986). Factors inhibiting performance of firms: an empirical investigation, Management International Review, 26, 33-43.

[17]. Lages, Luis Filipe and David B. Montgomery (2005), “The Relationship Between Export Assistance and Performance Improvement in Portuguese Export Ventures: An Empirical Test of the Mediating Role of Pricing Strategy Adaptation," European Journal of Marketing, 39 (7/8), 755-784.

[18]. Mahajar. A, Yunus. J and Razak. A, "Awareness of the Matrade Export Assistance Programs on Malaysian SMEs," American International Journal of Contemporary Research Vol. 4, No. 8; August 2014.

[19]. Marandu E.E. (1995). Impact of export promotion on export performance: a Tanzanian study, Journal of Global Marketing, 9, 9-39.

[20]. Moini A.H. (1998). Small firms exporting: how effective are government export assistance programs? Journal of Small Business Management, 36, 1-15.

[21]. Seringhaus and Rosson (1990). Government Export Promotion: A Global Perspective, Routledge, London. 